\title{
Behavioural species discrimination in red wood ants (Formica rufa group)
}

\author{
Matthieu Fleury, Christian Bernasconi, Anne Freitag, Pekka Pamilo \& Daniel Cherix
}

Keywords: Formica rufa group, red wood ants, taxonomy, behaviour, cryptic species, species identification

\section{Abstract}

The Formica rufa group (red wood ants) currently includes six species. Nevertheless, during previous work based on molecular markers, we showed the existence of one population morphologically identified as F. lugubris, but genetically different from all other analysed populations of this species. This population could represent a cryptic species within the Swiss National Park and has been provisionally named Formica lugubris-A2.

To verify our hypothesis, we conducted a behavioural test based on the ability of ants to recognize pupae of their own species when compared to those of another species. The three red wood ant species present in the Swiss National Park (F. lugubris, $F$. paralugubris and $F$. aquilonia) and the $F$. lugubris-A2 population were used in our study. Results indicate that the $F$. lugubris-A2 population differs from other $F$. lugubris and from all other species in the behaviour of its workers and in the way its pupae are discriminated by other species. This is in accordance with the genetic data and strengthens our hypothesis on the existence of a new cryptic red wood ant species within the Swiss National Park.
Profile

Protected area

Swiss National Park

Mountain range

Alps

Country

Switzerland

\section{Introduction}

Mound-building red wood ants (species of the Formica rufa group) belong to one of the most studied groups of ants in Europe (see Cotti 1963, 1995, 1996) and have fundamental roles and positive effects in forest ecosystems of the northern hemisphere (Pavan 1959, 1981; Jurgensen et al. 2008). Therefore, they are considered very promising species in forest ecosystems monitoring (Gösswald 1990). Because of their importance, red wood ants are protected by law in many European countries (Gösswald 1989), including Switzerland. However, despite this protection, some species are included on the IUCN Red List of threatened species (Hilton-Taylor 2000) and on the Red List of some countries like Switzerland (Agosti \& Cherix 1994).

The recent phylogenetic study conducted by Goropashnaya et al. (2004) suggested that at present the group consists of six species in Europe: F. rufa Linnaeus 1761; F. polyctena Förster 1850; F. lugubris Zetterstedt 1838; F. paralugubris Seifert 1996; F. aquilonia Yarrow 1955, and F. pratensis Retzius 1783. All these species have a very similar morphology and, in some cases, are able to hybridize (Czechowski 1993a; Seifert \& Goropashnaya 2004) or to form mixed colonies (Seifert 1991; Czechowski 1993b, 1996). As a consequence, the taxonomy of the group has always been debated and controversial (Pamilo et al. 1979; Vepsäläinen \& Pisarski 1981; Collingwood 1987; Seifert 1991) and many investigations were conducted to clarify it (Maeder \& Cherix 2001; Bernasconi et al. 2010 a, b).

A recent outcome of the numerous investigations on the F. rufa group was the description of F. paralugubris (Seifert 1996). After the discovery of two distinct

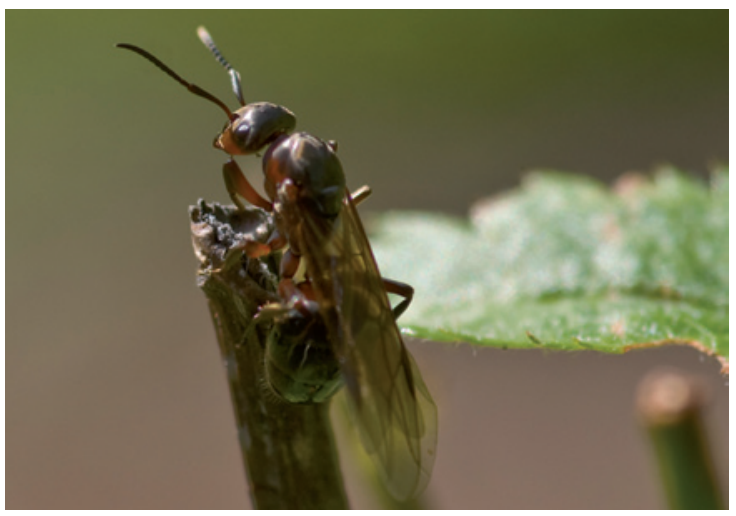

Formica lugubris-A2 queen. (C) Christian Bernasconi

morphotypes among F. lugubris queens (Kutter 1967, 1977), a broad range of taxonomic tools was used to examine the possibility of the existence of diverse F. lugubris species. For example, the ability of ants to recognize homocolonial pupae by means of chemical cues was used in a behavioural experiment called “pupa-carrying test" (Rosengren et al. 1994), first developed by Rosengren \& Cherix (1981). This tool is based on natural reactions shown by workers when offered a choice between conspecific and heterospecific pupae. The results of this test, in association with other studies on alarm pheromones (Cherix 1983) and allozymes (Pamilo et al. 1992), provided clear evidence that F. lugubris was in fact composed of two distinct species. This led to a comparative morphological study and the description of F. paralugubris (Seifert 1996). Afterwards, the pupa-carrying test conducted by Maeder et al. (2005) added further support to the species description. 
Table 1 - Location and identity of the sampled nests. Pupae and workers were sampled twice in nests marked by *; SCU2b substitutes SCU nest because of the lack of pupae in the latter nest during the second sampling (**).

\begin{tabular}{|c|c|c|c|}
\hline $\begin{array}{l}\text { Species / } \\
\text { Population }\end{array}$ & Study region & $\begin{array}{l}\text { Nest } \\
\text { ID }\end{array}$ & Coordinates \\
\hline \multirow[t]{5}{*}{ Formica aquilonia } & II Fuorn & SCR3 & $46^{\circ} 38^{\prime} 57 \mathrm{~N}, 10^{\circ} 10^{\prime} 52 \mathrm{E}$ \\
\hline & II Fuorn & SCR6 & $46^{\circ} 38^{\prime} 52 \mathrm{~N}, 10^{\circ} 10^{\prime} 44 \mathrm{E}$ \\
\hline & S-Charl/Val Mingèr & MIN1 & $46^{\circ} 43^{\prime} 47 \mathrm{~N}, 10^{\circ} 18^{\prime} 16 \mathrm{E}$ \\
\hline & S-Charl/Val Mingèr & MIN3 & $46^{\circ} 43^{\prime} 44 \mathrm{~N}, 10^{\circ} 18^{\prime} 15 \mathrm{E}$ \\
\hline & S-Charl/Val Mingèr & MIN4 & $46^{\circ} 43^{\prime} 43 \mathrm{~N}, 10^{\circ} 18^{\prime} 14 \mathrm{E}$ \\
\hline \multirow{5}{*}{ F. paralugubris * } & II Fuorn & P5A & $46^{\circ} 39^{\prime} 46 \mathrm{~N}, 10^{\circ} 12^{\prime} 21 \mathrm{E}$ \\
\hline & II Fuorn & P5B & $46^{\circ} 39^{\prime} 44 \mathrm{~N}, 10^{\circ} 12^{\prime} 23 \mathrm{E}$ \\
\hline & II Fuorn & $\mathrm{CHP} 15$ & $46^{\circ} 40^{\prime} 08 \mathrm{~N}, 10^{\circ} 11^{\prime} 20 \mathrm{E}$ \\
\hline & S-Charl/Val Sesvenna & SES1 & $46^{\circ} 43^{\prime} 08 \mathrm{~N}, 10^{\circ} 20^{\prime} 23 \mathrm{E}$ \\
\hline & S-Charl/Val Sesvenna & SES2 & $46^{\circ} 43^{\prime} 11 \mathrm{~N}, 10^{\circ} 20^{\prime} 27 \mathrm{E}$ \\
\hline \multirow[t]{5}{*}{ F. lugubris } & II Fuorn & P9B & $46^{\circ} 39^{\prime} 03 \mathrm{~N}, 10^{\circ} 15^{\prime} 38 \mathrm{E}$ \\
\hline & II Fuorn & FUO1 & $46^{\circ} 39^{\prime} 57 \mathrm{~N}, 10^{\circ} 12^{\prime} 21 \mathrm{E}$ \\
\hline & S-Charl/Val S-Charl & $\mathrm{SCH} 2$ & $46^{\circ} 42^{\prime} 25 \mathrm{~N}, 10^{\circ} 21^{\prime} 00 \mathrm{E}$ \\
\hline & S-Charl/Val S-Charl & $\mathrm{SCH} 3$ & $46^{\circ} 42^{\prime} 04 \mathrm{~N}, 10^{\circ} 21^{\prime} 21 \mathrm{E}$ \\
\hline & S-Charl/Val S-Charl & SCU2 & $46^{\circ} 46^{\prime} 00 \mathrm{~N}, 10^{\circ} 17^{\prime} 54 \mathrm{E}$ \\
\hline$* *$ & S-Charl/Val S-Charl & SCU $2 b$ & $46^{\circ} 45^{\prime} 57 \mathrm{~N}, 10^{\circ} 17^{\prime} 49 \mathrm{E}$ \\
\hline \multirow[t]{5}{*}{ F. lugubris-A2 } & S-Charl/Val Mingèr & MIN8 & $46^{\circ} 43^{\prime} 18 \mathrm{~N}, 10^{\circ} 17^{\prime} 56 \mathrm{E}$ \\
\hline & S-Charl/Val Mingèr & MIN15 & $46^{\circ} 43^{\prime} 08 \mathrm{~N}, 10^{\circ} 17^{\prime} 43 \mathrm{E}$ \\
\hline & S-Charl/Val Mingèr & MIN17 & $46^{\circ} 43^{\prime} 06 \mathrm{~N}, 10^{\circ} 17^{\prime} 38 \mathrm{E}$ \\
\hline & S-Charl/Val Mingèr & MIN18 & $46^{\circ} 43^{\prime} 03 \mathrm{~N}, 10^{\circ} 17^{\prime} 33 \mathrm{E}$ \\
\hline & S-Charl/Val Mingèr & MIN20 & $46^{\circ} 42^{\prime} 56 \mathrm{~N}, 10^{\circ} 17^{\prime} 14 \mathrm{E}$ \\
\hline
\end{tabular}

Despite the large amount and diversity of studies on the F. rufa group, no complete comparative study has been done exploring this group in its entirety and on a local scale. In order to fill this gap, we recently made a microsatellite analysis on the six species of the F. rufa group within the SNP area (Bernasconi et al. 2010b). In addition to the genetic differentiation of the six species, genetic data revealed the existence of a population morphologically described as F. lugubris, but genetically different from all other F. lugubris colonies and from all other wood ant species. This population, which will be referred to as $F$. lugubris- $A 2$ in this paper, could represent a new cryptic species of red wood ant (Bernasconi et al. 2010b).

As the existence of a new species can have a great influence on future conservation plans of these protected ants, we want to verify in this study the status of the population F. lugubris- $A 2$ compared with the species F. lugubris,

The difficult taxonomy of the F. rufa group is problematic in studies of ecology and biodiversity as the group is a dominant ant group in many European forest areas. Protected areas are key sites for promoting longterm species conservation and to study biodiversity as well as the evolution of species without human pressure. In such areas, biodiversity and density of some species can reach extremely high values as a result of ecosystems evolving naturally for years (i.e. butterflies, Pasche et al. 2007). Therefore, these areas also offer a great opportunity to collect and detect cryptic species. In most biodiversity studies as well as in monitoring projects, correct taxonomic assessment is a fundamental prerequisite to understanding, managing and preserving the natural world, especially in the face of the actual biodiversity crisis. Nevertheless, cryptic species which are morphologically hardly distinguishable (Bickford et al. 2007) represent a major challenge for correct species identification and a potential bias in biodiversity surveys and conservation plans. One good example of a key site for biodiversity studies is the Swiss National Park (SNP). Created in 1914, the SNP is a strict nature reserve (IUCN Category Ia) in the Engadin Valley, Canton of Grisons, in eastern Switzerland. The SNP and its surrounding area is probably one of the most suitable locations for studying red wood ants in Switzerland and in the Alps. All red wood ant species are present within this region and they are indeed very abundant within the park with a density of 1.8 nests / ha in forested habitat (Cherix et al. 2007). In addition, the park offers a unique opportunity to study the evolution of red wood ant populations in unmanaged forests.
F. paralugubris and F. aquilonia. We therefore used the pupa-carrying test to evaluate the ability of the four taxa to discriminate between alien and conspecific pupae and we are treating F. lugubris- $A 2$ as a separate species in our comparisons.

\section{Methods}

Study species and study area

The F. lugubris- $A 2$ population is located in the Mingèr Valley, situated at altitudes between $1700 \mathrm{~m}$ and $2100 \mathrm{~m}$ within the SNP (Bernasconi et al. 2010b). This population lives sympatrically with the three species F. lugubris, F. paralugubris and F. aquilonia in the unmanaged forests of this reserve (Cherix et al. 2007). In July 2008, we collected workers, worker pupae and nest material of the F. lugubris- $A 2$ population and of the species F. lugubris, F. paralugubris and F. aquilonia. The collection was taken at two sites $15 \mathrm{~km}$ apart within the SNP. In each site, 2 or 3 nests per species were sampled (Table 1). Sampling was done in July, when worker production and nest activity are at their peak. Nests are therefore able to recover rapidly from perturbations due to our sampling. Sampled nests were already known from earlier studies (Devenoges 1999; Maeder 2006) and species identification has been conducted on a morphological base according to Seifert (2007). These identifications were also confirmed by microsatellites (Bernasconi et al. 2010b). The collected material was kept in ventilated plastic boxes for a few days before experiments and workers were fed daily with water and a sugar mixture provided ad libitum. 
A

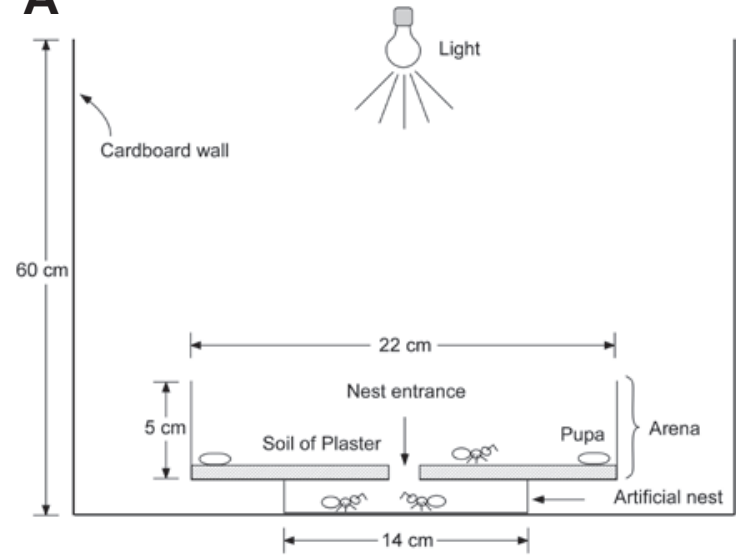

B

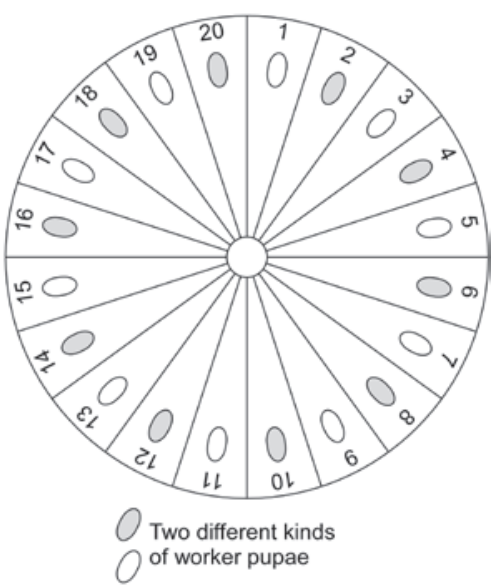

Figure 1 - A: Experimental device used for the pupa-carrying test. B: Arena with 20 sectors filled with ten homocolonial or conspecific pupae and ten heterocolonial or heterospecific pupae (adapted from Maeder et al. 2005).

\section{Experimental procedures}

We used the pupa-carrying test based on the sequencemethod experiment described by Rosengren and Cherix (1981) and Rosengren et al. (1994). The design was adapted from Maeder et al. (2005). Two kinds of tests were conducted to assess the discrimination ability of workers. First, we made intraspecific tests, in which workers were offered homocolonial (from the same nest) and heterocolonial (from another nest of the same species) pupae (Table 2; combinations 1, 5, 11, 16). Second, we made interspecific tests, in which workers were offered conspecific and heterospecific pupae (Table 2; combinations 2-4, 6-10, 12-15). Nests used for each experiment were chosen randomly among all collected nests.

Fifteen workers were chosen according to their behaviour as pupae carriers. They were placed in an artificial nest consisting of a small plastic box filled with material of their own nest and containing five homocolonial pupae (Figure 1A). A round arena with a central entry hole was placed on this artificial nest. The entry hole was covered with a small piece of cardboard to prevent ants from entering the arena before the beginning of the test. The wall of the arena was covered with fluon to prevent ants from escaping. The plaster surface of the arena was divided into 20 sectors of equal size (numbered from 1 to 20). In order to prevent ants from using external visual cues for orientation, the whole arena was surrounded by $50 \mathrm{~cm}$ high cardboard and was lit centrally by a light bulb.

We placed ten pupae of one kind in the odd-numbered sectors and ten pupae of another kind in the even-numbered sectors (Figure 1B). The experiment began when the arena entry hole was opened by removing the small piece of cardboard. We noted the order in which pupae were retrieved to the nest. The number of pupae of a kind remaining on the arena was reported when all pupae of the other kind had been retrieved to the nest. If no pupae were collected within 15 minutes or when the workers were too active

Table 2 - Pupa-carrying tests results. N: number of replicates; $S$ : number of tests with a significant preference for bomocolonial or conspecific pupae. The probabilities (p) from individual tests were combined as $\chi^{2}=-2 \Sigma \ln (p)$ with $d f=2 \mathrm{~N}$, and the significances are *** for $P<0.001$, ** for $P<0.01$ and ns for non-significant. For the discrimination index we give the mean and standard error (DI \pm S.E.) and the largest and smallest observed value for each combination.

\begin{tabular}{|l|l|l|r|r|r|r|r|r|}
\hline Combination & Heterocolonial or heterospecific pupae & Workers & $\mathbf{N}$ & $\mathbf{S}$ & $-\mathbf{2 \Sigma} \ln (\mathbf{p})$ & $\mathbf{D I} \pm \mathbf{S} . \mathbf{E}$. & $\mathbf{D I}_{\max }$ & $\mathbf{D I}_{\min }$ \\
\hline 1 & F. lugubris-A2 & F. lugubris-A2 & 15 & 0 & $28.8 \mathrm{~ns}$ & $0.3 \pm 0.6$ & 3 & -5 \\
\hline 2 & & F. lugubris & 15 & 14 & $247.8^{* * *}$ & $7.9 \pm 0.5$ & 10 & 3 \\
\hline 3 & & F. aquilonia & 15 & 13 & $291.0^{* * *}$ & $8.5 \pm 0.6$ & 10 & 2 \\
\hline 4 & & F. paralugubris & 15 & 14 & $294.7^{* * *}$ & $8.9 \pm 0.6$ & 10 & 2 \\
\hline 5 & & F. lugubris-A2 & 15 & 3 & $94.8^{* * *}$ & $3.1 \pm 0.9$ & 10 & -2 \\
\hline 6 & F. lugubris & 10 & 5 & $135.6^{* * *}$ & $6.2 \pm 1.2$ & 10 & 1 \\
\hline 7 & & F. aquilonia & 10 & 10 & $197.3^{* * *}$ & $8.8 \pm 0.5$ & 10 & 7 \\
\hline 8 & & F. paralugubris & 10 & 8 & $152.7^{* * *}$ & $7.3 \pm 0.8$ & 10 & 3 \\
\hline 9 & & F. lugubris-A2 & 15 & 7 & $143.6^{* * *}$ & $5.1 \pm 0.8$ & 10 & 1 \\
\hline 10 & & F. lugubris & 10 & 8 & $184.0^{* * *}$ & $8.1 \pm 1.0$ & 10 & 1 \\
\hline 11 & & F. aquilonia & 10 & 1 & $49.2^{* * *}$ & $2.4 \pm 1.0$ & 10 & -1 \\
\hline 12 & & F. paralugubris & 15 & 7 & $143.0^{* * *}$ & $4.5 \pm 1.0$ & 10 & -2 \\
\hline 13 & & F. lugubris-A2 & 15 & 4 & $126.8^{* * *}$ & $4.3 \pm 0.8$ & 10 & -1 \\
\hline 14 & & F. lugubris & 10 & 8 & $183.3^{* * *}$ & $8.2 \pm 0.8$ & 10 & 3 \\
\hline 15 & & F. aquilonia & 15 & 4 & $125.6^{* * *}$ & $4.3 \pm 0.9$ & 10 & -1 \\
\hline 16 & & F. paralugubris & 10 & 2 & $41.0^{* *}$ & $2.0 \pm 1.0$ & 7 & -2 \\
\hline
\end{tabular}




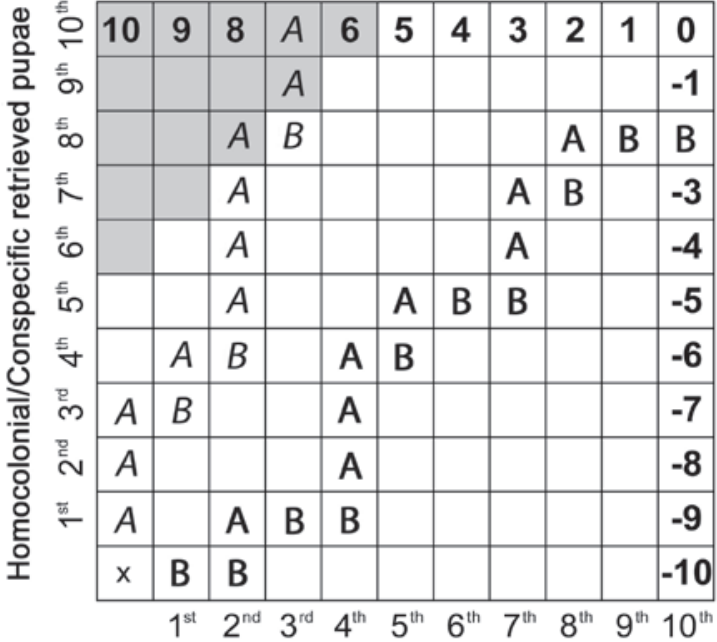

Heterocolonial/Heterospecific retrieved pupae

Figure 2 - Matrix used for the statistical worker choice test. The statistically significant area $(p \leq 0.05)$ is the shaded area which indicates a preference for the homocolonial or conspecific pupae (no case of statistical preference for heterocolonial or heterospecific pupae was observed); $x=$ starting point of the experiment. Each letter indicates a choice event: $A$ is a choice of a homocolonial or conspecific pupa, leading to one step up in the matrix, and $B$ is a choice of a beterocolonial or heterospecific pupa, leading to one step to the right. The numbers in the upper row and last column correspond to the discrimination index (DI). Bold sequence: the workers show no statistically significant preference and the discrimination index attributed to this test is -2. Italic sequence: the workers show a statistically significant preference for homocolonial or conspecific pupae, with a discrimination index of 7 (adapted from Maeder et al. 2005).

to allow us to record reliably the order in which pupae were retrieved to the nest, we discarded the replicate and repeated with new workers and pupae of the same nests.

After each experiment, workers were replaced in their ventilated plastic boxes and pupae were discarded. The arena surface was cleaned with water and the forceps with alcohol, to prevent deposition of chemical cues. We fixed the number of tests to avoid a second sampling as much as possible. Fifteen tests were made when F. lugubris-A2 pupae and/or workers were included (Table 2; combinations 1-5, 9, 13) and both F. paralugubris and F. aquilonia were involved (Table 2; combinations 12 and 15). For all other combinations, 10 tests were conducted (Table 2; combinations 6-8, $10-11,14,16)$.

\section{Statistical analyses}

Discrimination of pupae by workers was analysed using the worker choice test developed by Rosengren et al. (1994) and adapted by Maeder et al. (2005). A matrix was constructed to report the order in which workers retrieved the pupae to the nest (Figure 2). If the workers discriminate, they should first remove the pupae of their own colony (or own species) to safety, and the observations should deviate from the diagonal of the matrix into an area of statistical significance, as described in Maeder et al. (2005) (Figure 2). The area of significance is defined as those matrix squares which a random removal of the two types of pupae would enter with a total probability of 0.0336 .

A discrimination index (DI) was attributed to each test to combine results from replicate experiments. This index corresponds to the number of heterocolonial or heterospecific pupae remaining in the arena (1 to 10) when all pupae of the workers' own colony or own species have been removed. If the ten heterocolonial or heterospecific pupae were retrieved first, the DI receives a negative value given by the number of conspecific and own nest pupae remaining in the arena (-1 to -10 ) (Figure 2). Under the assumption of random choice, we calculate a probability for each DI value, and the probability of a test is then given as a cumulative probability of observing as strong or stronger discrimination by chance. The replicate experiments can then be combined by calculating $\chi^{2}=-2 \Sigma \ln (\mathrm{P})$ with $\mathrm{df}$ being twice the number of replicate tests. We also calculated the mean and standard error of DI for each worker-pupa combination. For each species (defined by the workers used in the test), we made a one-way ANOVA and then tested the differences of treatment between intraspecific and interspecific tests in pairwise comparisons with a Tukey HSD test.

\section{Results}

Out of a total of 231 replicates, 205 were conducted successfully. In the 26 other cases, three types of problems were observed: workers did not carry any pupae, too few pupae were retrieved, or the activity of workers was so high that we could not record the order in which the pupae were retrieved to the nest.

In general, all workers discriminated pupae of other species more than pupae from another conspecific nest. For all species, the mean DI returned the smallest value in the intraspecific tests (Table 2, Figure 3A, B, C, D). The intraspecific tests also showed that F. lugubris- $A 2$ workers did not discriminate efficiently between pupae from their own colony and from another colony, whereas all the other species did. Formica lugubris workers discriminated between conspecific colonies more strongly $(\mathrm{DI}=6.2)$ than F. lugubris-A2 workers discriminated alien species (DI from 3.1 to 5.1) .

The interspecific tests commonly had DI values ranging from 7.3 to 9.9, with some exceptions. First, F. lugubris- $A 2$ did not discriminate other species very strongly even though they showed significant discrimination. Second, the species F. aquilonia and F. paralugubris showed relatively weak, though significant, and similar discrimination in pairwise tests. The results in the pairwise tests between the other two species were clearly asymmetric, F. lugubris discriminating strongly against $F$. lugubris- $A 2$, whereas discrimination in the opposite direction was relatively weak. However, when compared with the intraspecific tests, the interspecific 
A F. lugubris-A2 workers

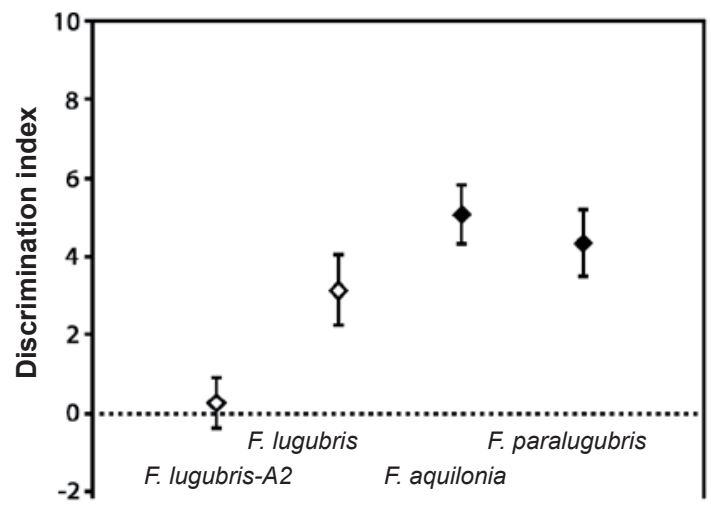

Non-nestmate pupae

C F. aquilonia workers

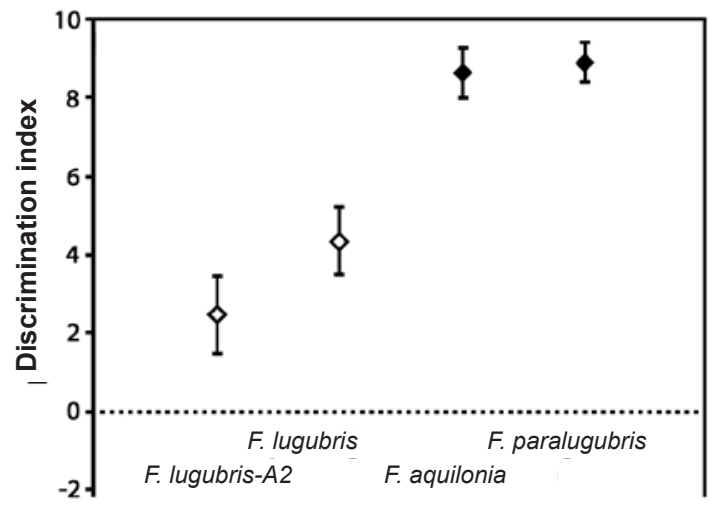

Non-nestmate pupae
B F. lugubris workers

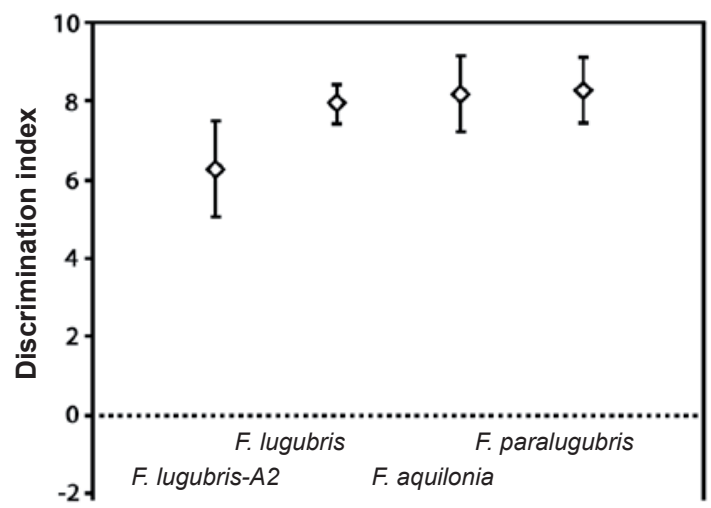

Non-nestmate pupae

D F. paralugubris workers

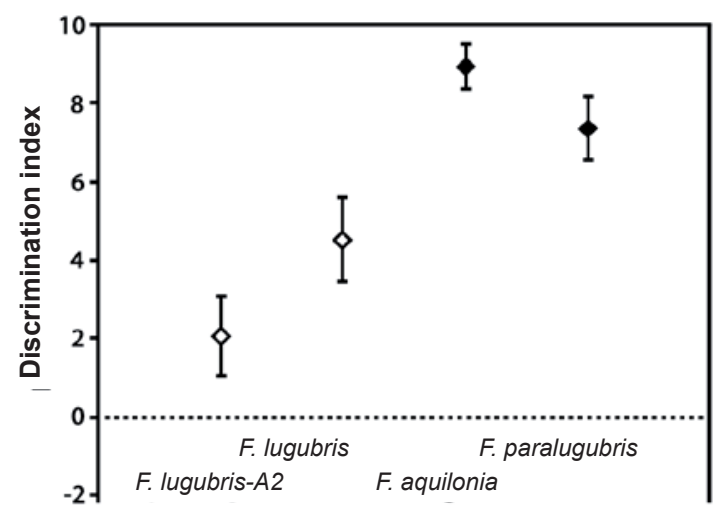

Non-nestmate pupae

Figure 3 -Mean discrimination indexes ( \pm S.E.) obtained in the pupa-carrying test. Results of each combination of tests are sorted by worker species or population. $A$ and $\mathrm{B}$ : for $\mathrm{F}$. lugubris-A2 and $\mathrm{F}$. lugubris, differences in discrimination index between the intraspecific tests with pupae of the same population and the others tests (interspecific and intraspecific with a different population) were tested by Tukey HSD. C and D: For F. aquilonia and F. paralugubris, differences in discrimination index between intraspecific tests and interspecific ones were tested by Tukey HSD. Open symbols: DI does not differ from the intraspecific test. Closed symbols: DI differs significantly $(p<0.003)$ from the intraspecific test.

tests between F. lugubris- $A 2$ and F. lugubris returned mean DIs which were slightly higher than those within the species.

Comparison of tests showed that the mean interspecific DI did not differ significantly from intraspecific DI within the pair F. lugubris- $A 2$ and F. lugubris on the one hand (Tukey's HSD, p $=0.060$ and 0.816) and between $F$. aquilonia and F. paralugubris on the other $(p=0.356$ and 0.227 , Figure 3). Interspecific discrimination between these pairs always significantly exceeded intraspecific differentiation $(p<0.003)$ except for the tests with F. lugubris workers, as they discriminated colonies of their own species so efficiently that the interspecific DIs did not differ significantly from the intraspecific DI ( $p=0.519$ and 0.540 , Figure $3 b)$.

\section{Discussion}

When offered the choice between conspecific pupae and F. lugubris-A2 pupae, workers of F. lugubris, F. paralugubris and F. aquilonia discriminated the latter, preferring to retrieve their own pupae to the nest. In addition, by retrieving an important number of heterocolonial or heterospecific pupae, F. lugubris- $A 2$ workers displayed a behaviour that differed greatly from the behaviour of workers of the other three species. Even though they are morphologically identified as a single species, F. lugubris and F. lugubris- $A 2$ showed the most conspicuous difference in their discriminative behaviours in our tests. F. lugubris displayed among the biggest discrimination indexes (Figure $3 \mathrm{~b}$ ) and F. lugubris- $A 2$ showed among the smallest (Figure $3 \mathrm{a}$ ). These results seem to be corroborated by preliminary aggression tests carried out in the field, during which about 20 workers belonging to two different nests were placed together in a common arena. F. lugubris$A 2$ and the three species F. lugubris, F. paralugubris and F. aquilonia were used, but only a reduced number of replicates for each intra- and inter-specific comparison were made (C. Bernasconi, unpublished data). Furthermore, present data are also coherent with our microsatellite analyses, which show that the population 
of F. lugubris- $A 2$ differs genetically from the sympatric populations of F. lugubris (Bernasconi et al. 2010b). Our results could also partly reflect the social type of the analysed species. F. lugubris-A2, like F. paralugubris and $F$. aquilonia, seems to be highly polygynous and polydomous (C. Bernasconi, unpublished data). On the other hand, F. lugubris is known to present both social types within the SNP (Bernasconi et al. 2005), even if only nests of polydomous colonies were selected in this study.

There are alternative hypotheses to explain the behaviour of F. lugubris-A2, depending on the nature of the chemical cues and the recognition system (see Crozier \& Pamilo 1996). One possibility is that F. lugubris-A2 results from hybridization between some of these genetically close species. As a result, F. lugubris-A2 workers could not detect cues in pupae of the other species as alien, whereas the other species could react to the alien cues in F. lugubris-A2 pupae (Guerrieri et al. 2009). However, our molecular data do not suggest that the population $F$. lugubris- $A 2$ is the result of an ongoing hybridization (Bernasconi et al. 2010b). Quite the opposite view is provided by the scenario that $F$. lugubris- $A 2$ has exceptionally low cue diversity. If the population represents an independent evolutionary lineage, it may be a rare species with small populations and population bottlenecks in its past history. That would predict reduced genetic diversity and it might even be expected that such a population with a low cue diversity could be discriminating other populations and species because they carry alien cues (Guerrieri et al. 2009). However, it is not clear whether this applies to recognition of pupae.

The small propensity to discriminate presented by F. lugubris-A2 workers does not necessarily mean that they are unable to distinguish between different pupae. They might be able to make the distinction between two kinds of pupae but both of them are retrieved to the nest. The habit to retrieve heterocolonial or heterospecific pupae to the nest is well known in Solenopsis invicta (Tschinkel 1992). Workers of this species often steal the brood of small incipient conspecific nests in order to accelerate their own colony maturity. Although never observed in species of the F. rufa group, a similar brood-raiding behaviour could eventually explain the behaviour of F. lugubris- $A 2$ in the pupa-carrying test (Kutter 1957, 1969). The ability to retrieve heterospecific pupae to their nest could also suggest a more extreme behaviour, displayed by slave-making ants (e.g. Formica sanguinea), which steal the brood of different species in order to obtain slave workers (see Mori et al. 2000), but the ability of F. lugubris- $A 2$ to steal a brood in natural conditions needs to be verified and is a matter of great interest for upcoming studies. In our study, we also observed great differences in behaviour between $F$. lugubris- $A 2$ and the three species F. lugubris, F. aquilonia and F. paralugubris. In particular, F. lugubris workers displayed higher discrimination values when faced with $F$. lugubris-A2 pupae than with other F. lugubris pupae, even though the difference did not reach the level of statistical significance $(p=0.06)$. Moreover, despite the fact that F. lugubris, F. aquilonia and F. paralugubris are the genetically closest species to F. lugubris-A2 within the Formica rufa group (Goropashnaya et al. 2004), they are genetically well separated from it (Bernasconi et al. 2010b). In addition, F. aquilonia and F. paralugubris, which represent two separate species, showed only weak discrimination ability between their pupae in interspecific tests. Consequently, the behaviour displayed by F. lugubris-A2 workers might indicate that the separation between $F$. lugubris and F. lugubris- $A 2$ is at least as important as between F. aquilonia and F. paralugubris. This agrees with our genetic results, which suggest that $F$. lugubris- $A 2$ could be a new cryptic species of the F. rufa group (Bernasconi et al. 2010b). The genetic results also indicate that the colonies of $F$. lugubris- $A 2$ studied here are polygynous and polydomous (like F. aquilonia and F. paralugubris), which may influence the recognition tests, and it is necessary to obtain additional evidence before the taxonomic status of the population can be firmly concluded. Further studies, such as morphological investigations and analyses of sexual pheromones of red wood ant species (Bernasconi et al., in prep.), are currently in progress and seem to add further support to our hypothesis. These results are of great interest for biodiversity, for the conservation of these ants and for the management of this protected area.

To date, Formica lugubris- $A 2$ has never been observed outside the SNP. Even if we should consider that Formica lugubris- $A 2$ could have been confused with $F$. lugubris so far and more studies are needed to clarify the distribution of the two species, this could indicate that this region is either the last refugium or represents a habitat which a population of a rare species with scattered distribution may have colonized. In future, more studies should be undertaken on the F. rufa group species in the alpine region. In fact, some authors suggested that other potential cryptic species could be hidden in the Alps. They highlighted the existence of scattered ice-free areas within the Alps or at their periphery during the last glacial maximum. In particular, high levels of endemism have been found in the southern, south-eastern, easternmost and northeastern Alps (Tribsch 2004). Numerous alpine plant and animal species persisted and developed independently in these refugia, which are now seen as centres of alpine species diversity and endemism (Stehlik 2000; Tribsch 2004; Schönswetter et al. 2005; Parisod 2008). Considering this particular situation and thanks to technical advances, more cryptic species of red wood ants might be discovered in Alpine valleys in the future. Further studies should therefore improve our knowledge of local biodiversity, giving new insights for management of Alpine protected areas. 


\section{Acknowledgments}

Many thanks are due to the Swiss National Park staff and the Canton of Grisons (Department of Nature and Environment) for allowing us to work in this beautiful landscape. The authors are also grateful to Joël Meunier and to Caroline Frey for their kind collaboration. This study has been supported by grants from the Société Vaudoise d'Entomologie and the Academy of Finland (122210). Our experiments were conducted and authorized in compliance with local and federal laws in Switzerland.

\section{References}

Agosti, D. \& D. Cherix 1994. Liste rouge des fourmis menacées de Suisse. Office fédéral de l'environnement, des forêts et du paysage (OFEFP) (eds). Berne.

Bernasconi, C., A. Maeder, D. Cherix \& P. Pamilo 2005. Diversity and genetic structure of the wood ant Formica lugubris in unmanaged forests. Annales Zoologici Fennici 42: 189-199.

Bernasconi, C., P. Pamilo \& D. Cherix 2010a. Molecular markers allow sibling species identification in red wood ants (Formica rufa group). Systematic Entomology 35 (2): 243-249.

Bernasconi, C., D. Cherix, B. Seifert \& P. Pamilo 2010b. Molecular taxonomy of the Formica rufa group (red wood ants): a new cryptic species in the Swiss Alps? Myrmecological News 14: 37-47.

Bickford, D., D.J. Lohman, N.S. Sohdi, P.K.L. Ng, R. Meier, K. Winker, K. Ingram \& I. Das 2007. Cryptic species as a window on diversity and conservation. Trends in Ecology and Evolution 22: 148-155.

Cherix, D. 1983. Intraspecific variations of alarm pheromones between two populations of the red wood ant Formica lugubris Zett. (Hymenoptera, Formicidae). Mitteilungen der Schweizerischen Entomologischen Gesellschaft 56: 57-65.

Cherix, D., D. Devenoges, A. Freitag, C. Bernasconi \& A. Maeder 2007. Premier recensement des fourmis des bois (groupe Formica rufa) au Parc National Suisse. Nationalpark-Forschung in der Schweiz 94: 69-79.

Collingwood, C.A. 1987. Taxonomy and zoogeography of the Formica rufa L. species group. In: Eder J. \& H. Rembold (eds.), Chemistry and biology of social insects: 65-67.

Cotti, G. 1963. Bibliografia ragionata 1930-1961 del gruppo Formica rufa in Italiano, Deutsch, English. Ministero dell' agricoltura e delle foreste, Roma.

Cotti G. 1995. Bibliografia ragionata 1962-1981 del gruppo Formica rufa in Italiano, Français, Deutsch. Istituto di Entomologia dell'Università di Pavia, Centro Interdisciplinare di Bioacustica e di Ricerche Ambientali, Roma.

Cotti, G. 1996. A bibliography of the Formica rufa group (Hymenoptera, Formicidae). Insect Social Life 1: 133-136.
Crozier, R.H. \& P. Pamilo 1996. Evolution of social insect colonies. Oxford.

Czechowski, W. 1993a. Hybrids in red wood ants (Hymenoptera: Formicidae). Annales Zoologici 44: 43-53.

Czechowski, W. 1993b. Mixed colonies of red wood ants (Hymenoptera: Formicidae). Annales Zoologici 44: 27-41.

Czechowski, W. 1996. Colonies of hybrids and mixed colonies; interspecific nest takeover in wood ants (Hymenoptera, Formicidae). Memorabilia Zoologica 50: 1-116.

Devenoges, A. 1999. Distribution des fourmis des bois (groupe rufa) au Parc National Suisse, PNS. Applications à l'aide d'un systéme d'information géographique, SIG. Diplôme de biologie, Université de Neuchâtel.

Goropashnaya, A.V., V.B. Fedorov, P. Pamilo 2004. Recent speciation in the Formica rufa group ants (Hymenoptera, Formicidae): inference from mitochondrial DNA phylogeny. Molecular Phylogeny and Evolution 32: 198-206.

Gösswald, K. 1989. Die Waldameise. Band 1: Biologische Grundlagen, Ökologie und Verbalten. Wiesbaden.

Gösswald, K. 1990. Die Waldameise. Band 2: Die Waldameise in Ökosystem Wald, ibr Nutzen und ibre Hege. Wiesbaden.

Guerrieri, F.J., V. Nehring, C.G. Jørgensen, J. Nielsen, C.G. Galizia \& P. d'Ettorre 2009. Ants recognize foes and not friends. Proceedings of the Royal Society B 276: 2461-2468.

Hilton-Taylor, C. (compiler) 2000. IUCN red list of threatened species. IUCN, Gland, Switzerland \& Cambridge, UK.

Jurgensen, M.F., L. Finer, T. Domisch, J. Kilpelainen, P. Punttila, M. Ohashi, P. Niemela, L. Sundstrom, S. Neuvonen \& A.C. Risch 2008. Organic moundbuilding ants: their impact on soil properties in temperate and boreal forests. Journal of Applied Entomology 132: 266-275.

Kutter H. 1957. Eine neue Form der Sklavengewinnung bei Ameisen. Umschau: 327-329.

Kutter, H. 1967. Variationsstatische Erhebungen an Weibchen von Formica lugubris Zett. Bulletin de la Société Entomologique Suisse 40: 63-77.

Kutter, H. 1969. Die sozialparasitischen Ameisen der Schweiz. Neujahrsblatt Naturforschende Gesellschaft in Zürich.

Kutter, H. 1977. Formicidae-Hymenoptera. Insecta Helvetica. Entomologisches Institut der ETH.

Maeder, A. \& D. Cherix 2001. Problèmes posés par Formica paralugubris une nouvelle espèce de fourmi des bois. Actes Colloques Insectes Sociaux 14: 21-25.

Maeder, A., A. Freitag \& D. Cherix 2005. Speciesand nestmate brood discrimination in the sibling wood ant species Formica paralugubris and Formica lugubris. Annales Zoologici Fennici 42: 201-212.

Maeder, A. 2006. Contribution to the conservation biology of the wood ant Formica lugubris (Hymenoptera, Formicidae) in Switzerland. PhD Thesis, University of Lausanne. 
Mori, A., D.A. Grasso, F. Le Moli 2000. Raiding and foraging behavior of the blood-red ant, Formica sanguinea Latr. (Hymenoptera, Formicidae). Journal of Insect Behavior 13: 421-438.

Pamilo, P., D. Chautems, D. Cherix 1992. Genetic differentiation of disjunct populations of the ants Formica aquilonia and Formica lugubris in Europe. Insectes Sociaux 39: 15-29.

Pamilo, P., K. Vepsäläinen, R. Rosengren, S. Varvio-Aho \& B. Pisarski 1979. Population genetics of Formica ants II. Genic differentiation between species. Annales Entomologici Fennici 45: 65-76.

Parisod, C. 2008. Postglacial recolonization of plants in the Western Alps of Switzerland. Botanica Helvetica 118: 1-12.

Pasche, A., Y. Gonseth \& D. Cherix 2007. Recherches sur les Lépidoptères diurnes au Parc National Suisse: résultats principaux. Nationalpark-Forschung in der Schweiz 94: 89-121.

Pavan, M. 1959. Attività italiana per la lotta biologica con formiche del gruppo Formica rufa contro gli insetti dannosi alle foreste. Ministero dell'agricoltura e delle foreste, Roma. Collana verde 4: 1-70.

Pavan, M. 1981. Utilizzazione delle formiche del gruppo Formica rufa nella difesa biologica delle foreste. In: Studi sulle formiche utili alle foreste, Ministero dell'agricoltura e delle foreste, Roma. Collana verde 59.

Rosengren, R. \& D. Cherix 1981. The pupa-carrying test as a taxonomic tool in the Formica rufa group. In: Howse P.E. \& J.-L. Clément (eds.), Biosystematics of social insects (Systematics Association Special Volume No.19): 263-281. London.

Rosengren, R., D. Chautems, D. Cherix, W. Fortelius \& L. Keller 1994. Separation of two sympatric sibling species of Formica L. ants by a behavioural choice test based on brood discrimination. Memorabilia Zoologica 48: 237-249.

Schönswetter, P., I. Stehlik, R. Holderegger \& A. Tribsch 2005. Moecular evidence for glacial refugia of mountain plants in the European Alps. Molecular Ecology 14: 3547-3555.

Seifert, B. 1991. The phenotypes of the Formica rufa complex in East Germany. Abhandlungen und Berichte des Naturkundemuseum Görlitz 65: 1-27.

Seifert B. 1996. Formica paralugubris nov. spec. - a sympatric sibling species of Formica lugubris from the western Alps (Insecta: Hymenoptera: Formicoidea: Formicidae). Reichenbacbia Staatliches Museum für Tierkunde Dresden 31: 193-201.

Seifert, B. \& A. Goropashnaya 2004. Ideal phenotypes and mismatching hyplotypes - errors of mtDNA treeing in ants (Hymenoptera: Formicidae) detected by standardized morphometry. Organisms, Diversity \& Evolution 4: 295-305.

Seifert, B. 2007. Die Ameisen Mittel- und Nordeuropas. Görlitz.

Stehlik, I. 2000. Nunataks and peripheral refugia for alpine plants during quaternary glaciation in the middle part of the Alps. Botanica Helvetica 110: 25-30.
Tribsch, A. 2004. Areas of endemism of vascular plants in the Eastern Alps in relation to Pleistocene glaciation. Journal of Biogeography 31: 747-760.

Tschinkel, W.R. 1992. Brood raiding and the population dynamics of founding and incipient colonies of the fire ant, Solenopsis invicta. Ecological Entomology 17: 179-188.

Vepsäläinen, K. \& B. Pisarski 1981. The taxonomy of the Formica rufa group: chaos before order. In: Howse P.E. \& J.L. Clément (eds.), Biosystematics of social insects. - Systematics Association Special Volume 19: 27-36.

\section{Authors}

\section{Matthieu Fleury}

is biologist and schoolteacher in sciences and geography. He holds a Master in biology, evolution and conservation from the University of Lausanne. For his master thesis, he worked on red wood ants of the Swiss National Park.

Christian Bernasconi $i^{1,2}$ - corresponding author is biologist and had his $\mathrm{PhD}$ working on red wood ants of the swiss national park under the supervision of professors Daniel Cherix and Pekka Pamilo. Currently he works as project manager for Pro Natura, a Swiss association for the conservation of nature. Christian.Bernasconi@pronatura.ch

\section{Anne Freitag ${ }^{2}$}

Anne Freitag is curator at the Museum of Zoology in Lausanne. She works on red wood ants ecology. With Daniel Cherix and Christian Bernasconi, she is currently working on a long-term monitoring project of red wood ants in Switzerland.

Anne.Freitag@vd.ch

\section{Pekka Pamilo ${ }^{3}$}

is a population geneticist working with ants. He has a $\mathrm{PhD}$ from Helsinki (1982) and postdocs in Australia and USA. He has held professorships in conservation biology (Uppsala 1990-2000), in genetics (Oulu 2000-2007)andinpopulationbiology(Helsinki2007-). pekka.pamilo@helsinki.fi

\section{Daniel Cherix ${ }^{1,2}$}

is curator at the Museum of Zoology in Lausanne, associate professor at the University of Lausanne and member of the federal commission of the swiss national parks. He works mostly on ant ecology but also on invasive species in Switzerland and on Galapagos. Daniel.Cherix@unil.ch

1 Department of Ecology and Evolution, University of Lausanne, 1015 Lausanne, Switzerland.

2 Museum of Zoology, Palais de Rumine, Place de la Riponne 6, 1014 Lausanne, Switzerland.

3 Present address: Department of Biosciences, Box 65, 00014 University of Helsinki, Finland. 